\title{
Bovine Milk Whey for Preparation of Natural $N$-glycans: Structural and Quantitative Analysis
}

\author{
Nongluk Sriwilaijaroen ${ }^{1,4}$, Sachiko Kondo ${ }^{2,3}$, Hirokazu Yagi ${ }^{2}$, Hiroaki Hiramatsu ${ }^{4}$, Shin-ichi \\ Nakakita $^{5}$, Keita Yamada ${ }^{6}$, Hiromi Ito ${ }^{7,8}$, Jun Hirabayashi ${ }^{6,8}$, Hisashi Narimatsu ${ }^{8}$, Koichi Kato ${ }^{2,3,9,10}$ \\ and Yasuo Suzuki ${ }^{4,11^{*}}$ \\ ${ }^{I}$ Faculty of Medicine, Thammasat University (Rangsit Campus), Pathumthani, Thailand \\ ${ }^{2}$ Graduate School of Pharmaceutical Sciences, Nagoya City University, Aichi, Japan \\ ${ }^{3}$ GLYENCE Co., Ltd., Aichi, Division of Functional Glycomics Japan \\ ${ }^{4}$ Health Science Hills, College of Life and Health Sciences, Chubu University, Kasugai, Aichi, Japan \\ ${ }^{5}$ Division of Functional Glycomics, Life Science Research Center, Institute of Research Promotion, Kagawa University, \\ 1750-1 Ikenobe, Miki-cho, Kita-gun, Kagawa 761-0793, Japan \\ ${ }^{6}$ Division of Glyco-Bioindustry, Kagawa University, Kagawa, Japan \\ ${ }^{7}$ School of Medicine, Fukushima Medical University, Fukushima, Japan \\ ${ }^{8}$ National Institute of Advanced Industrial Science and Technology (AIST), Tsukuba, Ibaraki, Japan \\ ${ }^{9}$ Institute for Molecular Science and Okazaki Institute for Integrative Bioscience, National Institutes of National Scienc- \\ es, Aichi, Japan \\ ${ }^{10}$ The Glycoscience Institute, Ochanomizu University, Tokyo, Japan \\ ${ }^{11}$ Global COE Program for Innovation in Human Sciences, University of Shizuoka, School of Pharmaceutical Sciences, \\ Shizuoka, Japan
}

\begin{abstract}
Glycans exhibit enormous structural diversity in nature and are of particular importance for self-cell survival and are often targeted by microbes. In this study, $N$-glycans $(374.9 \mathrm{pmol} / \mathrm{mg}$ in dry delipidated weight) were enzymatically released from bovine milk whey protein concentrate, and they were isolated and analyzed by a two-dimensional HPLC mapping technique and/or by MALDI-TOF mass spectrometry. A total of 39 identified $N$-glycans are bi- and tri-antennary sugar chains terminated with multiple mannose residues (Man-Man; molar ratio of 39.5\%), $\mathrm{N}$-acetyl-lactosamine (LacNAc; Gal $\beta 1-4 \mathrm{GlcNAc}$; molar ratio of 17.9), di- $N$-acetylated lactosamine (LacdiNAc; GalNAc $\beta 1-4 \mathrm{GlcNAc}$; molar ratio of 22.8), GlcNAc (molar ratio of 7.05), Neu5Ac $\alpha 2-6 \mathrm{Gal} \beta 1-4 \mathrm{GlcNAc}$ (molar ratio of 5.3), Neu5Ac $\alpha 2-6 \mathrm{GalNAc} \beta 1-4 \mathrm{GlcNAc}$ (molar ratio of 1.25), Neu5Gc $\alpha 2-6 \mathrm{Gal} \beta 1-4 \mathrm{GlcNAc}$ (molar ratio of 2.5), and Neu5Gc $\alpha 2-3 \mathrm{Gal} \beta 1-4 \mathrm{GlcNAc}$ (molar ratio of 0.25 ), in which some are fucosylated on the proximal core GlcNAc1-N-Asn. Terminal Neu5Aca2-3Gal/GalNAc and Neu5Gc $\alpha 2-3 / \alpha 2-6 \mathrm{GalNAc}$ were not detected in the bovine whey protein concentrate. Among the 39 glycans, GalNAc $\beta 1-$ 4GlcNAc $\beta 1-2 M a n \alpha 1-3$ (GalNAc $\beta 1-4 G l c N A c \beta 1-2 M a n \alpha 1-6) M a n \beta 1-4 G l c N A c \beta 1-4 G l c N A c \beta-$ and Man $\alpha 1-2 M a n \alpha 1-2 M a n \alpha$ 1-3(Man $\alpha 1-2$ Man $\alpha 1-3(\operatorname{Man} \alpha 1-2 M a n \alpha 1-6)$ Man $\alpha 1-6)$ Man $\beta 1-4 G l c N A c \beta 1-4 G l c N A c \beta-$ were the most abundant types found with molar ratios of 11.3 and 10, respectively. Elucidation of glycan molecular structures will lead to an understanding of their biological roles and functions. Whey contains a variety of glycans and is inexpensive, and it is thus considered to be source of glycans for array glycan libraries to be used for investigations of specific glycan-protein interactions, enabling not only analysis of biological roles of the glycan-binding proteins but also development of molecules affecting these interactions. Furthermore, these natural glycans may have therapeutic value in prevention and inhibition of infection of microbes that recognize them.
\end{abstract}

Keywords: Bovine milk whey, $N$-glycan, HPLC mapping, microarray, glycan-binding protein.

*Address correspondence to this author at the Department of Biomedical Sciences, College of Life and Health Sciences, and Health Science Hills, Chubu University, 1200 Matsumoto-cho, Kasugai-shi, Aichi, 487-8501, Japan; Tel/Fax: +81 56851 6391; E-mail: suzukiy@isc.chubu.ac.jp

\section{INTRODUCTION}

Whey is the liquid part separated from the solid part of milk (curd) by mixing milk with harmless active bacteria 
(providing acid whey with a $\mathrm{pH}$ lower than 5.1) or the enzyme rennin (providing sweet whey with a $\mathrm{pH}$ of at least 5.6) in a coagulation (clotting) process, the basis of cheese production. Generally, about $9 \mathrm{~L}$ of whey is produced as a byproduct for every kilogram of cheese-making [1]. Whey was previously considered as dairy industrial waste, but the functionality and nutritive value of whey are now recognized [2].

Whereas unstable proteins and most fats coagulate into the curd portion, most of the lactose, minerals, fast-acting proteins and vitamins are in the whey portion. Although there is composition variation of whey depending the type of cheese production and the milk composition varying due to season, species, etc., whey is generally composed of $61-75 \%$ lactose, $10-15 \%$ protein, $7-14 \%$ ash, $0.2-2 \%$ fat, moisture $\leq 5 \%$ for dry product and $\leq 95 \%$ for liquid product, and lactic acid $\leq 0.16 \%$ for sweet-type whey and $\geq 0.35 \%$ for acidictype whey [3]. Whey can be further processed into three different forms: isolate (the purest form containing at least $90 \%$ protein), concentrate (the cheapest form containing not less than $25 \%$ protein) and hydrolysate (hypoallergenic form that is pretreated with enzymes to break down amino acid chains). Whey protein has a number of applications in the food industry, such as in baked goods, beverages and nutritional supplements, due to its functionality and nutritive value [4].

Proteins are normally found to be covalently linked to oligosaccharides (glycans) that have several biological roles and are sometimes involved in pathogen interaction. $\mathrm{N}$ linked glycans, a major class of glycans that contain terminal $\mathrm{N}$-acetylglucosamine glycosidically linked to the amide group of asparagine located within the motif $\mathrm{N}-\mathrm{X}-\mathrm{S} / \mathrm{T} / \mathrm{C}$, by which X can be any amino acid residue except proline, play important roles in a variety of biological processes in addition to their strong influence on structure and function of their attached proteins. $\mathrm{N}$-glycans also appear to play an important role in pathogen infection; hence, whereas $N$-glycan type on the host cell surface is a critical determinant of pathogen infection (Most pathogens bind to specific glycans.), substances with specific glycans can bind and inhibit specific pathogens. For example, alpha 1,2-linked fucosylated glycans found in human milk have been shown to inhibit binding of diarrhea-causing pathogens, including campylobacter, enterotoxigenic Escherichia coli and caliciviruses, and to protect breast-feeding infants from infectious diarrhea [5]. Analysis of $\mathrm{N}$-glycans from bovine whole milk during the early lactation stage using a chemoselective glycoblotting technique and MALDI-TOF/TOF MS analysis revealed that the $\mathrm{N}$-glycosylation profile of bovine milk glycoproteins changes over time in relation to $\mathrm{N}$-glycosylation changes of $\mathrm{IgG}$, which is a major immunoglobulin component present in bovine colostrum [6]. In this study, we analyzed the composition and structures of $\mathrm{N}$-linked glycans derived from commercial whey protein concentrate by two-dimensional HPLC mapping in combination with MALDI-TOF/TOF MS techniques and quantitative comparison of $\mathrm{N}$-glycans by a fluorescence-based technique that enables determination of low picomole quantities of $\mathrm{N}$-glycans. The data gave a natural glycan source of a microarray for checking binding specific interaction with glycan-binding proteins (lectins) such as immune cells and pathogens.

\section{MATERIALS AND METHODOLOGY}

\section{Preparation of Pyridylaminated $N$-glycans from Bovine Milk Whey Protein Concentrate}

Whey protein used in this study is NZMP ${ }^{\mathrm{TM}}$ Whey Protein Concentrate 392 (Fonterra, Japan) containing $80.3 \mathrm{~g}$ protein, $3.7 \mathrm{~g}$ moisture, $6.2 \mathrm{~g}$ fat, $7.0 \mathrm{~g}$ total carbohydrate, and $2.8 \mathrm{~g}$ ash per $100 \mathrm{~g}$ dry weight. The following experiments were performed as described previously [7]. In brief, dried whey $(30 \mathrm{mg})$ was delipidated with sequential extraction by $80 \%$ ethanol, $100 \%$ ethanol, chloroform/methanol $(2: 1, \mathrm{v} / \mathrm{v})$, chloroform/methanol/ $\mathrm{H}_{2} \mathrm{O}(1: 2: 0.8, \mathrm{v} / \mathrm{v} / \mathrm{v})$, and $80 \%$ acetone, respectively. The delipidated whey extract $(22.5 \mathrm{mg})$ was then proteolyzed with pepsin and the resultant glycopeptides were further digested with glycoamidase A. $N$ glycans were released and the peptides were further hydrolyzed to amino acids or very short peptides by pronase treatment. The $\mathrm{N}$-glycans were purified by gel filtration on a Bio-Gel P-2 column $(1 \mathrm{~cm}$ i.d. $\times 30 \mathrm{~cm})$ and evaporated to dryness. The reducing ends of the $\mathrm{N}$-glycans were then aminated with a fluorescent reagent, 2-aminopyridine (PA), for quantitative investigation. The PA-glycans were purified by gel filtration on a Sephadex G-15 column $(1 \mathrm{~cm}$ i.d. $\times 38 \mathrm{~cm})$ and lyophilized.

\section{Isolation and Characterization of PA-glycans}

The purified PA-glycans were separated using three different columns of high-performance liquid chromatography (HPLC) under conditions described previously $[7,8]$. In these HPLC systems, PA-glycans were detected by fluorescence using excitation and emission wavelengths of 320 and 400 $\mathrm{nm}$, respectively. The PA-glycan mixture was firstly separated on a TSKgel diethylamino ethanol (DEAE)-5PW column (7.5 mm i.d. $\times 75 \mathrm{~mm}$; Tosoh, Tokyo, Japan) at $30^{\circ} \mathrm{C}$ with a flow rate of $1.0 \mathrm{~mL} / \mathrm{min}$ using two solvents, A and B. Solvent $\mathrm{A}$ was $10 \%$ acetonitrile in water adjusted to $\mathrm{pH} 7.3$ with triethylamine, and solvent B was 3\% acetic acid in water adjusted to $\mathrm{pH} 7.3$ with triethylamie before mixing with acetonitrile at a ratio of 90:10 by volume. The column was equilibrated with solvent $\mathrm{A}$. The gradient elution parameters were 5-40 min and linear gradient of 0\%-20\% B. Each oligosaccharide was separated according to its anionic charges. Each fraction separated from the DEAE column was collected, evaporated, and then applied to a Shim-pack HRCoctadecyl silica (ODS) column $(6.0 \mathrm{~mm}$ i.d. $\times 150 \mathrm{~mm}$; Shimadzu, Kyoto, Japan). Elution was performed at a flow rate of $1.0 \mathrm{~mL} / \mathrm{min}$ at $55^{\circ} \mathrm{C}$ using two solvents, $\mathrm{C}$ and D. Solvent $\mathrm{C}$ was $10 \mathrm{mM}$ sodium phosphate buffer ( $\mathrm{pH}$ 3.8) and solvent D was $10 \mathrm{mM}$ sodium phosphate buffer ( $\mathrm{pH}$ 3.8) containing $0.5 \%$ 1-butanol. The column was equilibrated with solvent C. The gradient elution parameters were $0-60 \mathrm{~min}$ and linear gradient of $20 \%-50 \%$ D. The elution time of each peak was recorded in glucose unit (GU) value. The individual fractions were subjected to matrix-assisted laser desorption/ionizationtime of flight mass spectrometry (MALDI-TOF-MS). Fractions, including some $N$-glycans, were further separated by normal-phase chromatography using a TSKgel Amide- 80 column (4.6 mm i.d. $\times 250 \mathrm{~mm}$; Tosoh, Tokyo, Japan) based on molecular size and GU values recorded. In this system, two solvents, $\mathrm{E}$ and $\mathrm{F}$, were used at $40^{\circ} \mathrm{C}$. Solvent $\mathrm{E}$ was composed of $3 \%$ acetic acid in water with triethylamine $(\mathrm{pH}$ 
7.3) and acetonitrile at a ratio of $35: 65$ by volume, and solvent $\mathrm{F}$ was composed of $3 \%$ acetic acid in water with triethylamine $(\mathrm{pH} 7.3)$ and acetonitrile at a ratio of $35: 65$ by volume. The column was equilibrated with solvent $\mathrm{E}$. The gradient elution parameters were $0-30 \mathrm{~min}$ and linear gradient of $0 \%-60 \% \mathrm{~F}$. The identification of $\mathrm{N}$-glycan structures was based on GU and mass values in comparison to PAglycans in the GALAXY database (http://www.glycoanalysis.info/galaxy2/ENG/systemin1.jsp) [9]. Then the structures were confirmed by co-chromatography with the reference PA-glycans. The sample PA-glycans that had no agreement with any of the PA-glycan structures registered in the GALAXY database were characterized by sequential treatments with exoglycosidases ( $\alpha 2,3$-sialidase, $\alpha$-sialidase, $\alpha$-galactosidase, $\beta$-galactosidase, $\alpha$ - $N$-acetylhexosaminidase and $\alpha$-L-fucosidase) under conditions described previously [7] until they became identical to the known reference PAglycans in the database as described previously [8].

\section{RESULTS}

$\mathrm{N}$-glycans released from whey protein concentrate after sequential digestion with protease and glycoamidase A could be separated into 4 peaks with differences in charge at retention times of 2.5, 3.3, 11.3 and 12.7 min on the DEAE column (Fig. 1a). The earliest eluted fraction was neutral with a molar ratio about 39.4 followed by more negatively charged fractions with molar ratios of 18.0, 25.2 and 17.4, respectively. Peak 2 could not be eluted after injection into an ODS column. In addition, in the absence of the whey sample, there was a peak at the position of peak 2 on the DEAE col-

(a)

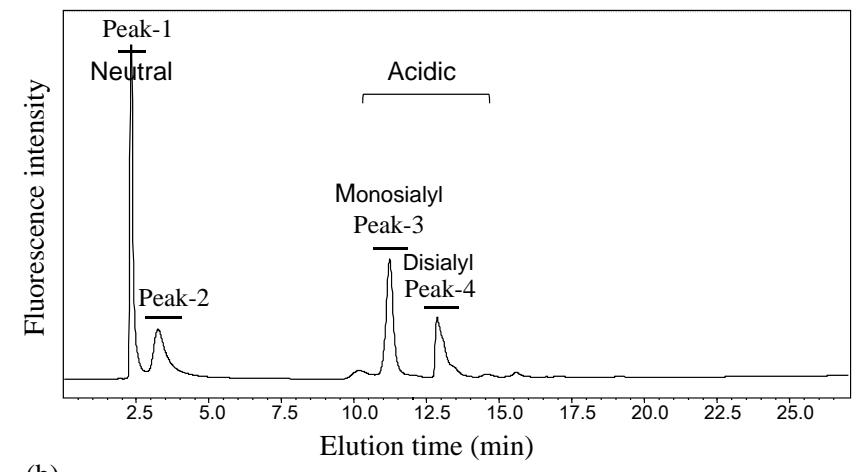

(b)

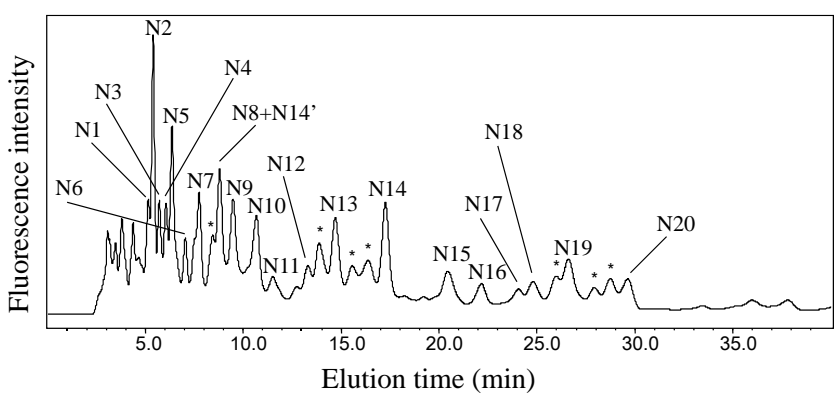

umn. These results suggested that some materials used in the DEAE analysis process may be derivatized with the fluorescent PA. The negatively charged fractions are due to a sialic acid component(s) released when these fractions were treated with neuraminidase from Arthrobacter ureafaciens. On the ODS-silica column, neutral, mono-sialylated and disialylated fractions were separated, with a very hydrophilic fraction being eluted first and more hydrophobic fractions being eluted later, into N1-N20 fractions (Fig. 1b), M1-M8 fractions (Fig. 1c) and D1-D5 fractions (Fig. 1d), respectively. Each sample fraction collected from the ODS column was further analyzed by MALDI-TOF-MS, demonstrating that N8, N9, N10, N13, N15, N19 and M4' fractions contain more than one type of $\mathrm{N}$-glycan and that M1' and M3' fractions are epimers of M1 and M3 fractions, respectively. The epimers are by-products formed in the reaction of pyridylamination. N8, N9, N10, N13, N15, N19 and M4' fractions were then separated by size using an amide-silica column into N8 and N14', N9a, N9b and N9c, N10a and N10b, N13a and N13b, N15a and N15b, N19a and N19b, and M4' and M5', respectively (graphs not shown). MALDI-TOF-MS analysis indicated that M4' and M5' are by-product epimers of M4 and M5, respectively. Twenty-four molecules from a total of 35 identified molecules showed coincidence of their elution coordinates with that of the corresponding standard PA-glycans. Eleven molecules corresponding to fractions N10a, N10b, N15a, N15b, M1, M2, M4, M5, M7, M8 and D2 were not identical with any known standard PA-glycans in the Galaxy database. These new molecules that have not so far been registered in Galaxy database were identified by

(c)

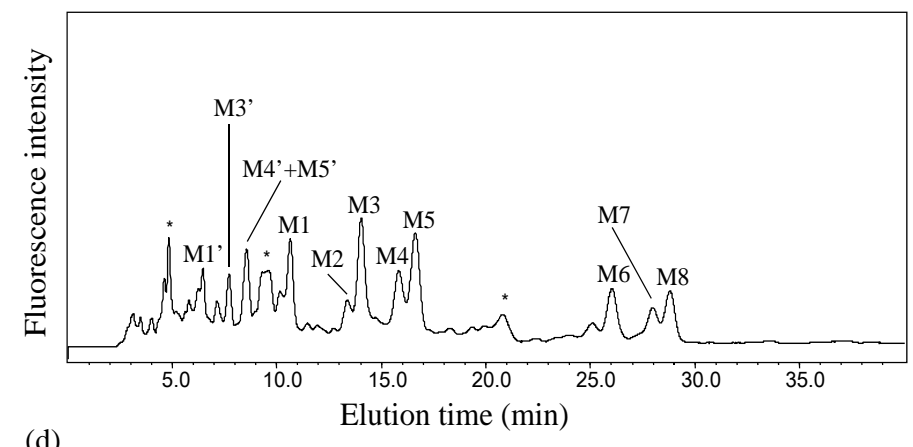

(d)

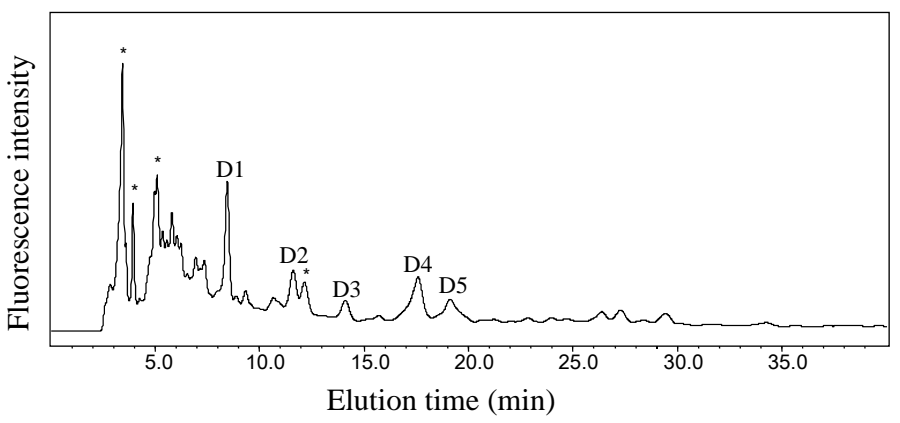

Fig. (1). HPLC chromatograms of PA- $N$-glycans from bovine milk whey protein concentrate. (a) After purification, fluorescence (PA)labeled $\mathrm{N}$-glycans were fractionated on an anion exchange DEAE column according to their negatively charged sialic acid content. The resulting neutral (b), mono-sialylated (c) and di-sialylated (d) fractions were individually separated on a reversed-phase ODS column according to hydrophobicity. Quantification of each PA- $N$-glycan fraction was based on peak area measured at Ex/Em of 320/400 nm. N, M and D indicate neutral, mono-sialylated and di-sialylated $\mathrm{N}$-glycans, respectively. An asterisk (*) indicates a non PA-sugar chain. 
sequential trimming with several exo-glycosidases as described in Materials and Methods. The resultant PA-glycans at each step of the trimming were co-chromatographied with the standard PA-glycans. These trimming and cochromatography processes were performed until the sample PA-glycans became identical to the standard PA-glycans. This identity was confirmed by MALDI-TOF-MS analysis. Due to the specificities of the exoglycosidases used, the original structures of the trimmed PA-glycans were revealed uniquely. Therefore, we identified the structures of all $35 \mathrm{~N}$ glycans (374.9 pmol/mg in dry delipidated weight) derived from bovine whey protein concentrate. Details of each structure are shown in Table $\mathbf{1}$.

All identified $N$-linked glycans of bovine whey protein possess a common trimannosyl core, Man $\alpha 1-6($ Man $\alpha 1-$ 3) Man $\beta 1-4 G l c N A c \beta 1-4 G l c N A c$, linked to asparagine in the -Asn-X-Ser/Thr- sequence of the polypeptide. According to the addition of sugar residues to the trimannosyl core, $\mathrm{N}$ glycans were classified into three groups: (1) high-mannose type (2) hybrid type and (3) complex type. $\mathrm{N}$-glycans from bovine whey protein concentrate exist as all of these $N$ glycan types. High-mannose types contain mannose residues with up to 6 residues attached to the core. The largest highmannose type carries three antennae present in fraction $\mathrm{N} 2$ and appeared to be the predominant high-mannose type with a molar ratio of 10 (Fig. 1b and Table 1). Hybrid types of bovine whey protein $N$-glycans contain GalNAcGlcNAc (LacdiNAc), GalGlcNAc (lactosamine, LacNAc) or Neu5 Ac2-6GalGlcNAc on one antenna (3-arm of the trimannosyl core) with or without extra mannose residues connected to the core on the other antenna (6-arm of the core). Some hybrid types contain fucose on the proximal core GlcNAc (core fucose). Complex structures containing GlcNAc elongated with or without Gal or GalNAc in the presence of sialic acid (Neu5Ac or Neu5Gc) on both of the $\alpha 3$ - and $\alpha 6$-linked mannoses of the core have the largest number and the largest amount of $\mathrm{N}$-glycans from bovine whey protein (highmannose:hybrid:complex, number: 8:8:23; molar ratio: $33.2: 12.6: 50.7)$. Some complex $N$-glycans are fucosylated on the core GlcNAc through the $\alpha 1,6$ linkage. The most abundant $N$-glycan present in bovine whey protein is complex type with LacdiNAc on both 3-arm and 6-arm of the core with a molar ratio of 11.3 (fraction N14+N14') as shown in Fig. (1b) and Table 1.

Sugar residues and linkage type at the outer termini of $N$ glycan structures are of prime importance for interaction with other molecules or cells. The outer termini of $N$-glycans derived from bovine whey protein concentrate are neutral high-mannose, Gal $\beta 1-4 \mathrm{GlcNAc}$, GalNAc $\beta 1-4 \mathrm{GlcNAc}$, GlcNAc $\beta 1-2 M a n$, and acidic Neu5Aco2-6Gal, Neu5Ac $\alpha 2-$ 6GalNAc, Neu5Gca2-6Gal, Neu5Gca2-3Gal with molar ratios of $39.5,17.85,22.8,7.05,5.3,1.25,2.5$ and 0.25 , respectively; hereby, neutral:acid glycans are equal to 87.2:9.3 molar ratio (Fig. 2). It is particularly noteworthy that a major type of sialic acid in bovine whey protein, Neu5Ac, was found to be conjugated to Gal or GalNAc with $\alpha 2-6$ linkage only, whereas the other major sialic acid, Neu5Gc, bears either $\alpha 2-6$ or $\alpha 2-3$-linked Gal but not GalNAc.

\section{DISCUSSION}

$\mathrm{N}$-glycan structures of glycoproteins indicate their biological roles and functions including cell-cell interaction and pathogen binding. A total of $39 \mathrm{~N}$-glycans quantitatively detected from protein of bovine whey protein concentrate are composed of 26 neutral and 13 acidic sugars. $N$-Glycome was detected in bovine whole milk during the early lactation stage in a previous study [6]. In additional to general factors including diet, environment, seasons and species, $\mathrm{N}$-glycan variations in bovine milk might have resulted from stages of lactation; a strong association between glycosylation and lactation period has been shown [6]. Unlike glycoblotting and MALDI-TOF MS analysis [6], our 2D HPLC-mapping technique and MALDI-TOF MS analysis before and after exo-glycosidase sequential digestion enabled not only elucidation of the $\mathrm{N}$-glycan composition but also determination of the detailed $\mathrm{N}$-glycan structures including glycosidic linkage and isomeric monosaccharide discrimination. $N$-Glycans in bovine whey carried bi- or tri-antennae. Tetra-antennary glycans could not be detected, possibly because their amount in the whey is very small. Lactophorin isolated from cow's milk whey contains tetra-antennary $\mathrm{N}$-glycans [10]; however, only a small amount of lactophorin is present in whey ( $0.023 \%$ weight by weight) [11].

One of the most abundant $\mathrm{N}$-glycan structures detected in bovine whey protein concentrate is high-mannose-type triantennary glycan $\left(\mathrm{Man}_{9} \mathrm{GlcNAc}_{2}\right)$ with a molar ratio of 10 . $\mathrm{Man}_{9} \mathrm{GlcNAc}_{2}$ is a typical high-mannose type of $\mathrm{N}$-glycan found in a variety of cell types, such as porcine trachea and lung [12], and chorioallantoic and amniotic cells [13], but are generally found at low levels; most $\mathrm{Man}_{9} \mathrm{GlcNAc}_{2}$ might be converted by $\alpha 1,2$-mannosidase in the endoplasmic reticulum (ER) to $\mathrm{Man}_{5} \mathrm{GlcNAc}_{2} \mathrm{~N}$-glycans. However, $\mathrm{Man}_{9} \mathrm{Glc}-$ $\mathrm{NAc}_{2}$ has also been observed to be the predominant $\mathrm{N}$-glycan in tora bean [14]. Man ${ }_{9} \mathrm{GlcNAc}_{2}$ is a glycan structure recognized by a dendritic cell surface receptor called dendritic cell-specific ICAM-3-grabbing nonintegrin (DC-SIGN) that is important for host immune response and for enabling entry of $\mathrm{Man}_{9} \mathrm{GlcNAc}_{2}$-enveloped viruses into host cells [15]. Thus, bovine whey protein concentrate is a useful $\mathrm{Man}_{9} \mathrm{GlcNAc}_{2}$ source for determining recognition specificity, screening inhibitory compounds, and design of antiviral inhibitors.

The complex-type biantennary $\mathrm{N}$-glycan bearing both ending arms of LacdiNAc is the major $\mathrm{N}$-glycan isolated from the bovine whey concentrate, accounting for $11.3 \%$ of total $\mathrm{N}$-glycans. $\mathrm{N}$-glycans possessing terminal LacdiNAc account for $22.8 \%$ of total $\mathrm{N}$-glycans, a level that is approximately 1.7-times lower than that of terminal high-mannose type. LacdiNAc can be modified by other sugars, such as sulfate, fucose and sialic acid. Only an $\alpha 2-6$ sialylated LacdiNAc structure was detected in bovine whey protein concentrate; this modified form is frequently found in vertebrates [16].

Although LacNAc termini on glycoconjugates in vertebrates are more common than the LacdiNAc structure, the amount of $\mathrm{N}$-glycans derived from bovine whey protein concentrate bearing LacNAc is about 1.3-times smaller than the 
Table 1. Code Number, Structures and Relative Quantity of $N$-glycans from Bovine Milk Whey Protein Concentrate

\begin{tabular}{|c|c|c|c|c|}
\hline $\begin{array}{c}\text { Peak Code } \\
\text { No. }\end{array}$ & $\begin{array}{c}\text { GU } \\
(\text { ODS })\end{array}$ & $\begin{array}{c}\text { Molecular } \\
\text { Weight (Da) }\end{array}$ & Structures & Relative Quantity (\%)* \\
\hline \multicolumn{5}{|c|}{$\begin{array}{l}\text { Neutral Glycans } \\
\text { High-Mannose-Type } \\
\end{array}$} \\
\hline $\begin{array}{c}\text { N1 } \\
\text { M8.1 }\end{array}$ & 5.0 & 1800 & $\begin{array}{l}\text { Man } \alpha 2 \text { Man } \alpha 6 \text { 、'Man } \alpha 6 \text { 、'Man } \beta 4 \text { GleNAc } \beta 4 \text { GlcNAc-PA } \\
\text { Man } \alpha 3 \text { ' } \\
\text { Man } \alpha 2 \text { Man } \alpha 2 \text { Man } \alpha 3\end{array}$ & 2.2 \\
\hline $\begin{array}{c}\text { N2 } \\
\text { M9.1 }\end{array}$ & 5.3 & 1962 & $\begin{array}{l}\text { Man } \alpha 2 \text { Man } \alpha 6 \text { 、'Man } \alpha 6 \text { 、'Man } \beta 4 \text { GlcNAc } \beta 4 G l c N A c-P A \\
\text { Man } \alpha 2 \text { Man } \alpha 3 \text { 'Man } 22 \text { Man } \alpha 2 \text { Man } \alpha 3\end{array}$ & 10.0 \\
\hline $\begin{array}{c}\text { N3 } \\
\text { M8.4 }\end{array}$ & 5.6 & 1800 & $\begin{array}{l}\text { Man } \alpha 2 \text { Man } \alpha 6 \text { 、'Man } \alpha 6 \text { 、'Man } \beta 4 \text { GlcNAc } \beta 4 G l c N A c-P A \\
\text { Man } \alpha 2 \text { Man } \alpha 3 \text { ' } \\
\text { Man } \alpha 2 \text { Man } \alpha 3\end{array}$ & 1.8 \\
\hline $\begin{array}{c}\text { N5 } \\
\text { M6.1 }\end{array}$ & 6.2 & 1475 & 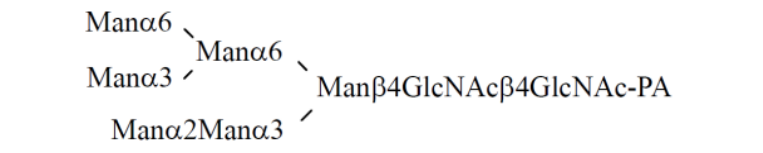 & 4.8 \\
\hline $\begin{array}{c}\text { N6 } \\
\text { M7.7 }\end{array}$ & 6.8 & 1638 & $\begin{array}{c}\text { Man } \alpha 6 \text { 、'Man } \alpha 6 \text { 、'Man } \beta 4 \text { GlcNAc } \beta 4 \text { GlcNAc-PA } \\
\text { Man } \alpha 2 \text { Man } \alpha 3 \text { ' } \\
\text { Man } \alpha 2 \text { Man } \alpha 3 \text { ' }\end{array}$ & 2.0 \\
\hline \multicolumn{5}{|l|}{ Hybrid type } \\
\hline $\begin{array}{c}\text { N9 } \\
100.4 a\end{array}$ & 8.3 & 1395 & 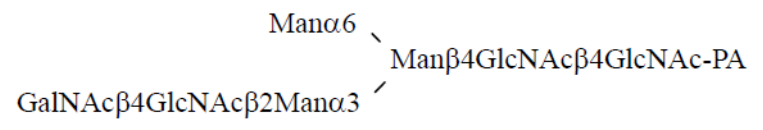 & 0.5 \\
\hline $\begin{array}{c}\text { N9 } \\
\text { H4.12 }\end{array}$ & 8.3 & 1516 & $\begin{array}{c}\text { Man } \alpha 3, \text { Man } \alpha 6 \text {, Man } \beta 4 \text { GlcNAc } \beta 4 \text { GlcNAc-PA } \\
\text { Gal } 34 \text { GlcNAc } \beta 2 \text { Man } \alpha 3\end{array}$ & 0.5 \\
\hline $\begin{array}{c}\mathrm{N} 9 \\
\mathrm{H} 4.12 \mathrm{a}\end{array}$ & 8.3 & 1557 & 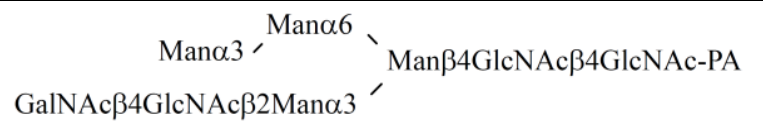 & 1.4 \\
\hline $\begin{array}{c}\text { N10 } \\
\text { H5.22 }\end{array}$ & 9.0 & 1679 & 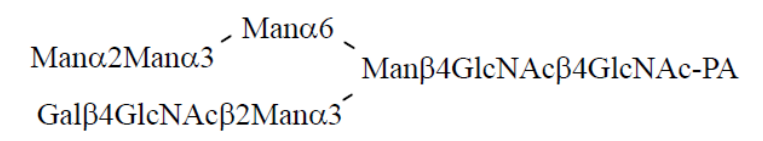 & 2.8 \\
\hline $\begin{array}{c}\mathrm{N} 10 \\
\text { H5.22a }\end{array}$ & 9.0 & 1720 & $\begin{array}{l}\text { Man } \alpha 2 \text { Man } \alpha 3^{- \text {Man } \alpha 6} \text {, Man } \beta 4 \text { GlcNAc } \beta 4 \text { GlcNAc-PA } \\
\text { GalNAc } \beta 4 \text { GlcNAc } \beta 2 \text { Man } \alpha 3^{\prime}\end{array}$ & 2.1 \\
\hline
\end{tabular}


Table 1. Contd.

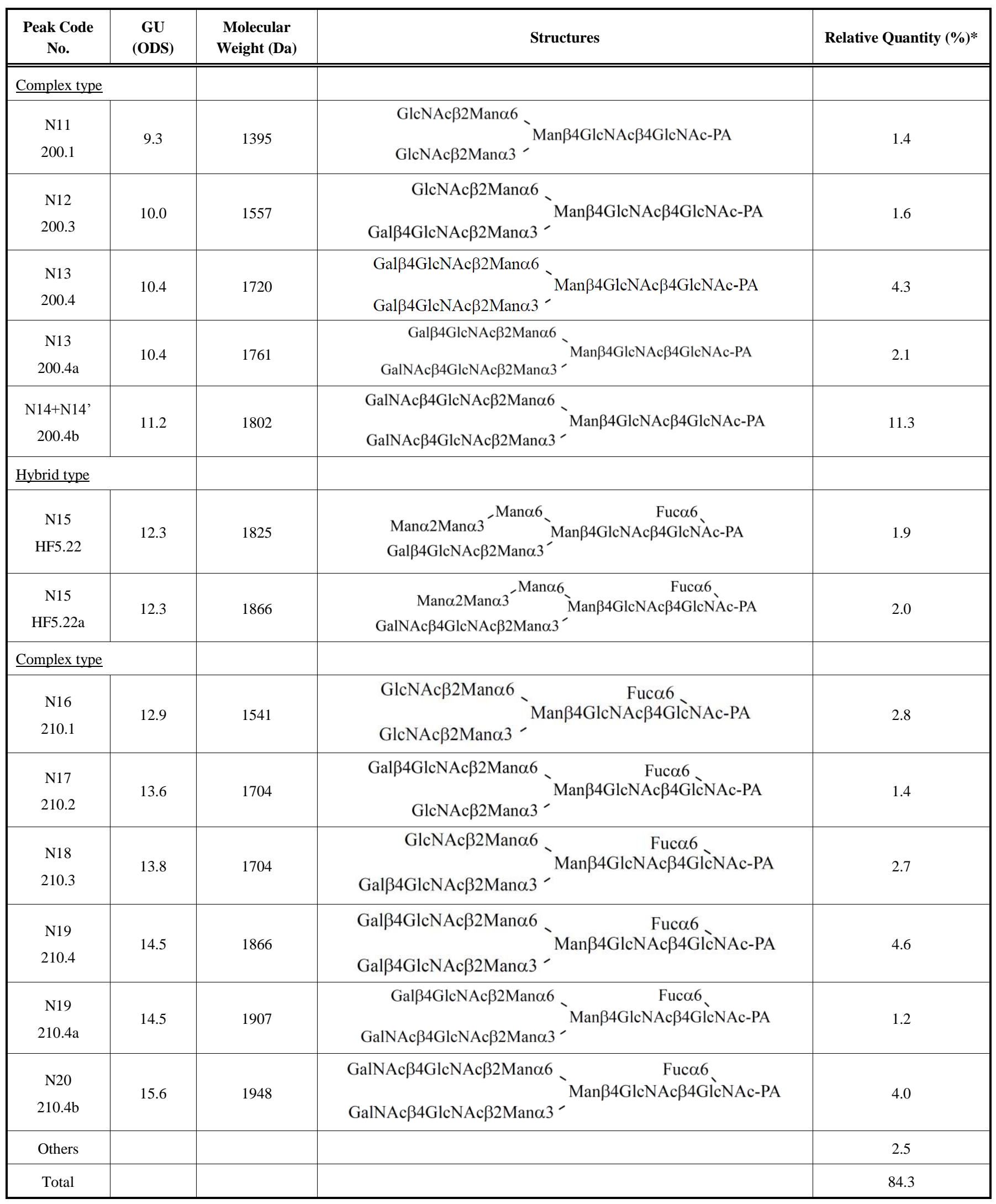


Table 1. Contd.

\begin{tabular}{|c|c|c|c|c|}
\hline $\begin{array}{l}\text { Peak Code } \\
\text { No. }\end{array}$ & $\begin{array}{c}\text { GU } \\
(\text { ODS })\end{array}$ & $\begin{array}{c}\text { Molecular } \\
\text { Weight (Da) }\end{array}$ & Structures & Relative Quantity $(\%)^{*}$ \\
\hline \multicolumn{5}{|c|}{$\begin{array}{l}\text { Monosialylated Glycans } \\
\text { Hybrid type }\end{array}$} \\
\hline $\begin{array}{c}\mathrm{M} 1+\mathrm{M} 1 \\
\text { 1A1-H5.22 }\end{array}$ & 9.0 & 1970 & $\begin{array}{c}\text { Man } \alpha 2 \text { Man } \alpha 3 \\
\text { Neu5Ac } \alpha 6 \text { Gal } \beta 4 \text { GlcNAc } \beta 2 \text { Man } \alpha 3^{\prime}\end{array}$ & 1.4 \\
\hline \multicolumn{5}{|l|}{ Complex type } \\
\hline $\begin{array}{c}\mathrm{M} 2 \\
1 \mathrm{~A} 1-200.4 \mathrm{a}\end{array}$ & 10.1 & 2052 & 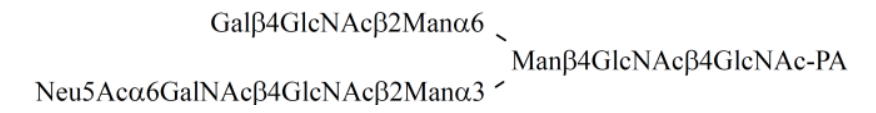 & 0.4 \\
\hline $\begin{array}{l}\text { M3+M3' } \\
1 \mathrm{~A} 1-200.4\end{array}$ & 10.3 & 2011 & $\begin{array}{l}\text { Gal } \beta 4 \text { GlcNAc } \beta 2 \text { Man } \alpha 6 \text { - Man } \beta 4 \text { GlcNAc } \beta 4 \text { GlcNAc-PA } \\
\text { Neu5Ac } \alpha 6 \text { Gal } \beta 4 G l c N A c \beta 2 M a n \alpha 3^{-}\end{array}$ & 2.2 \\
\hline $\begin{array}{c}\text { M5+M5 } \\
\text { 1A1-200.4a1 }\end{array}$ & 11.0 & 2052 & $\begin{array}{l}\text { GalNAc } \beta 4 \text { GlcNAc } \beta 2 \text { Man } \alpha 6 \text { 、'Man } \beta 4 \text { GlcNAc } \beta 4 \text { GlcNAc-PA } \\
\text { Neu5Ac } \alpha 6 \text { Gal } \beta 4 \text { GlcNAc } \beta 2 \text { Man } \alpha 3^{\prime}\end{array}$ & 2.5 \\
\hline $\begin{array}{c}\text { M6 } \\
\text { 1A1-210.4 }\end{array}$ & 14.3 & 2157 & 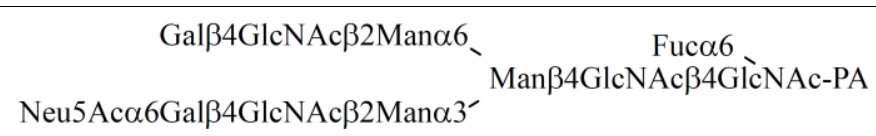 & 1.1 \\
\hline $\begin{array}{c}\text { M7 } \\
1 \mathrm{~A} 1-210.4 \mathrm{~b}\end{array}$ & 15.0 & 2239 & 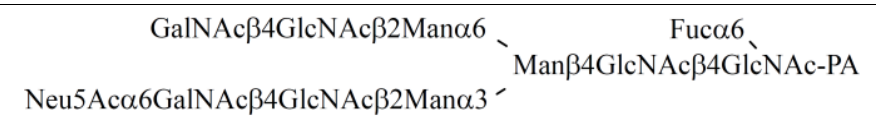 & 0.7 \\
\hline \multicolumn{5}{|c|}{ Disialylated Glycans } \\
\hline $\begin{array}{c}\text { D1 } \\
\text { 2G1-200.4 }\end{array}$ & 7.6 & 2334 & $\begin{array}{l}\text { Neu5Gc } \alpha 6 \text { Gal } \beta 4 G l c N A c \beta 2 M a n \alpha 6 \text {, Man } \beta 4 G l c N A c \beta 4 G l c N A c-P A \\
\text { Neu5Gc } \alpha 6 \text { Gal } \beta 4 G l c N A c \beta 2 M a n \alpha 3^{-}\end{array}$ & 1.5 \\
\hline $\begin{array}{l}\text { D2 } \\
1 \mathrm{G} 1-1 \mathrm{~A} 2- \\
200.4\end{array}$ & 9.3 & 2317 & $\begin{array}{l}\text { Neu5Ac } \alpha 6 \text { Gal } \beta 4 \text { GlcNAc } \beta 2 \text { Man } \alpha 6 \text { 、' Man } \beta 4 \text { GlcNAc } \beta 4 \text { GlcNAc-PA } \\
\text { Neu5Gc } \alpha 6 \text { Gal } \beta 4 \text { GlcNAc } \beta 2 \text { Man } \alpha 3^{-}\end{array}$ & 0.7 \\
\hline $\begin{array}{c}\text { D3 } \\
\text { 2G1-210.4 }\end{array}$ & 10.2 & 2480 & $\begin{array}{l}\text { Neu5Gc } \alpha 6 \mathrm{Gal} \beta 4 \mathrm{GlcNAc} \beta 2 \mathrm{Man} \alpha 6 \text { 、 } \\
\text { Neu5Gc } \alpha 6 \mathrm{Gal} \beta 4 \mathrm{GlcNAc} \beta 2 \mathrm{Man} \alpha 3^{-}\end{array}$ & 0.4 \\
\hline $\begin{array}{c}\text { D4 } \\
2 \mathrm{~A} 1-200.4\end{array}$ & 11.3 & 2302 & $\begin{array}{l}\text { Neu5Ac } \alpha 6 \text { Gal } \beta 4 G l c N A c \beta 2 M a n \alpha 6 \text { 、 } \\
\text { Neu5Ac } \alpha 6 \text { Gal } \beta 4 G l c N A c \beta 2 M a n \alpha 3^{-}\end{array}$ & 0.8 \\
\hline $\begin{array}{c}\text { D5 } \\
\text { 2G3-210.4 }\end{array}$ & 11.8 & 2480 & $\begin{array}{l}\text { Neu5Gc } \alpha 3 \mathrm{Gal} \beta 4 \mathrm{GlcNAc} \beta 2 \mathrm{Man} \alpha 6 \text { 、 } \\
\text { Neu5Gc } \alpha 6 \mathrm{Gal} \beta 4 \mathrm{GlcNAc} \beta 2 \mathrm{Man} \alpha 3^{-}\end{array}$ & 0.5 \\
\hline
\end{tabular}


Table 1. Contd.

\begin{tabular}{|c|c|c|c|c|}
\hline & $\begin{array}{c}\text { GU } \\
(\text { ODS })\end{array}$ & $\begin{array}{c}\text { Molecular } \\
\text { Weight (Da) }\end{array}$ & Structures & Relative Quantity (\%)* \\
\hline \hline Others & & & & 0.5 \\
\hline Total & & & & 4.4 \\
\hline
\end{tabular}

amount of $\mathrm{N}$-glycans carrying LacdiNAc on their terminal antennae. The LacNAc glycan sequence appears to be a receptor of some human pathogens such as enteropathogenic Escherichia coli (EPEC) [17]. Bovine whey protein concentrate could thus provide protection against intestinal pathogens mediated by LacNAc for infection.

The amount of acidic $N$-glycans derived from bovine whey protein concentrate consisting of Neu5Ac and/or Neu$5 \mathrm{Gc}$ is 9.4-times smaller than that of neutral $N$-glycans. Neu5Ac $\alpha 2-6$ Gal $\beta 1-4 G l c N A c$ (or Neu5Ac $\alpha 2-6 L a c N A c$ ) is the most prominent acidic glycan terminus followed by Neu5Gc $\alpha 2-6 \mathrm{Gal} \beta 1-4 \mathrm{GlcNAc}$ (or Neu5Gc $\alpha 2-6 \mathrm{LacNAc}$ ), Neu5Ac $\alpha 2-6$ GalNAc $\beta 1-4 G l c N A c$ (or Neu5Ac $\alpha 2-6 L a c d i N A c)$ and Neu5Gc $\alpha 2-3 \mathrm{Gal} \beta 1-4 \mathrm{GlcNAc}$ (or Neu5Gc $\alpha 2-3 \mathrm{Lac}-$ NAc). No Neu5Ac attached to Gal or GalNAc in an $\alpha 2-3$ linkage and no Neu5Gc attached to GalNAc either in an $\alpha 2-$ 3 or $\alpha 2-6$ linkage could be detected, possibly due to the presence of very low levels or the absence of these $N$ glycans in bovine whey protein concentrate. This might be a consequence of low or no expression of specific sialytransferase.

Sialylated $\mathrm{N}$-glycans are involved in a wide range of biological processes (such as cell-cell communication) and pathological events (such as the spreading of cancer), as well as pathogenesis (such as infection of several pathogens including influenza viruses, malarial parasites, and cholera bacteria) $[18,19]$. Only Neu5Ac and Neu5Gc, which are the two most common types of sialic acid found in mammalian cells from more than 50 sialic acid types known in nature, were identified in bovine whey protein concentrate. The other common "primary" sialic acid, 2-keto-3-deoxy-D-glyceroD-galacto-nononic acid (KDN; deaminated Neu5Ac), found in animals was not detected in $\mathrm{N}$-glycans from bovine whey protein concentrate. The Neu5Ac:Neu5Gc ratio varies among animal species, tissues and developmental stages. The molar ratio of Neu5Ac:Neu5Gc derived from bovine whey protein concentrate is 2.4 ; however, it has been suggested that bovine milk components may be altered depending on the lactation stage [6]. Differences in biological roles of Neu5Ac and Neu5Gc are less well understood. Some sialic acid-binding proteins can distinguish Neu5Ac from Neu5Gc. For example, Escherichia coli K99 and coronavirus causing serious diarrheal diseases in pigs have high affinity to Neu5Gc over Neu5Ac [20,21]. All H1N1 avian-like and classical swine influenza viruses isolated from pigs, which are typically mutated at position 155 in their hemagglutinin from Thr to Val/Ile, have been shown to have increased affinity for the Neu5Gc receptor [22]. Since sialic acids have important roles in determination of the biological functions of glycoproteins and that of the host range of some pathogens requiring sialic acids for infection, we are now isolating sialylated $N$-glycans from bovine whey protein concentrate for more studies on protein-glycan interactions.

Not only the terminal sialic acid residue but also the glycosidic linkage between the sialic acid and the next sugar

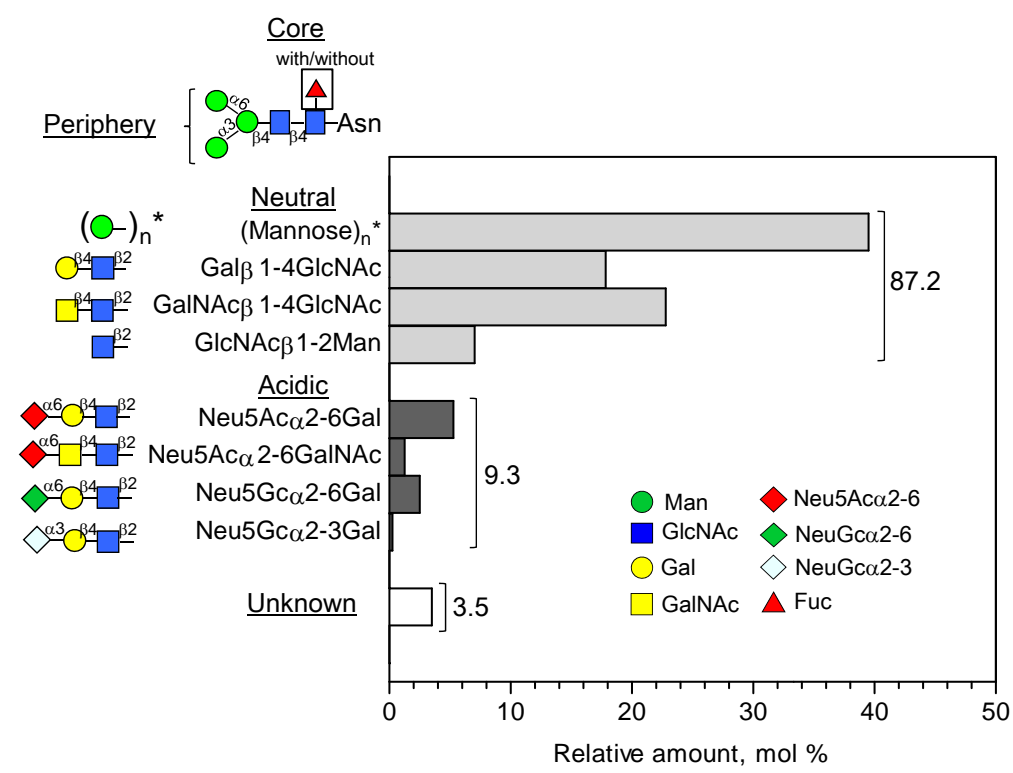

Fig. (2). Types and relative amounts of $N$-glycans isolated from bovine milk whey divided according to terminal sugar residues of the outer chains attached to the $\mathrm{Man}_{3} \mathrm{GlcNAc}_{2}$ core. "n", which is indicated by an asterisk (*), is the number of mannose residues (from 0 to 6 ) connected to the core structure. 
internal residue influence the biological roles of these $\mathrm{N}$ glycans. The two most common linkages, $\alpha 2-3$ and $\alpha 2-6$ linkages, were detected in sialylated $\mathrm{N}$-glycans from bovine milk protein concentrate in this study. Only one compound containing an $\alpha 2-3$ linkage, Neu5Gc $\alpha 2-3 \mathrm{Gal} \beta 1-4 \mathrm{GlcNAc}$ attached to a common core sugar sequence, was identified. This sialylated linkage could be used for characterization of the receptor binding specificity of influenza viruses from ducks and horses that preferentially bind to Neu5Gca2-3Galcarrying receptors $[23,24]$.

The $N$-glycosylation profile of $\mathrm{IgG}$, a major glycoprotein in bovine milk, was shown to be affected by $\alpha(2-3,6,8,9)$ sialidase treatment but not by $\alpha(2-3)$-sialidase treatment, suggesting that the sialylated linkage on $\operatorname{IgG}$ is $\alpha 2-6$ [6]. This is in agreement with our finding that the $\alpha 2-6$-sialylated $\mathrm{N}$-glycans derived from bovine milk protein concentrate are more abundant than $\alpha 2-3$-sialylated $N$-glycans by about 36.2 molar percent, and they are composed of Neu5Ac/ Neu5Gc $\alpha 2-6 \mathrm{Gal} \beta 1-4 \mathrm{GlcNAc}$ and Neu5Ac $\alpha 2-6 \mathrm{GalNAc} \beta 1$ 4GlcNAc. Previous studies also showed that $N$-glycans derived from bovine IgM, present in bovine whey [25], mainly terminated with Neu5Ac/Neu5Gca2-6Gal [26]. These a2-6linked sialylated glycans could be useful for determination of human-adapted influenza viruses and for study of the properties of several human cancers, including colon, breast and cervix cancers, associated with Sia 2 -6Gal $\beta 1-4 \mathrm{GlcNAc}$ level on their cell surface $[19,27]$.

Internal glycan modifications, such as fucosylation and sulfation, may influence the interaction between carbohydrates and proteins. However, no modification of the antennae of $\mathrm{N}$-glycans from bovine whey protein concentrate was detected. There was only introduction of fucose residue to the initial GlcNAc of the $N$-glycan core (core fucose) of some $\mathrm{N}$-glycans.

Due to the essential and important roles of lectins in interactions with glycans, including host-pathogen interactions, and in the immune system and homeostasis, many efforts have been made to determine the roles of lectins and their specific glycan ligands in order to control immunity and establish effective therapy for many glycan interactionassociated diseases, such as influenza and cancer. We have revealed the $\mathrm{N}$-glycan structures derived from bovine whey protein concentrate that could be used as a source for studies on glycan binding specificity on microarrays, results of which should lead to an understanding of the nature of glycan-protein interactions and methods for diagnosis/prevention/treatment of the diseases mentioned above.

\section{ACKNOWLEDGEMENT}

A part of this paper was supported from the grant of JGRID (Y.S.) and Grants-in-Aid for Young Scientists (B) (H.Y., 22790076) from the Ministry of Education, Culture, Sports, Science and Technology of Japan.

\section{REFERENCES}

[1] Tunick MH. Whey protein production and utilization: a brief history. In: Onwulata CI, Huth PJ, Eds. Whey processing, functionality and health benefits. Ames, Iowa: Blackwell Publishing and IFT Press 2008; pp. 1-14.
[2] Fox PF. Lactose: chemistry and properties. In: McSweeney PLH, Fox PF, Ed. Advanced Dairy Chemistry: Lactose, Water, Salts and Minor Constitutents. New York: Springer 2009; pp. 1-16.

[3] Committee on Food Chemicals Codex, Food and Nutrition Board, Institute of Medicine. Food chemicals codex. 5th ed. Washington, DC: National Academies Press 2003.

[4] In: Dunford M, Doyle A, Eds. Proteins. Nutrition for sport and exercise. Belmont: Wadsworth Cengage Learning 2008; pp. 15197.

[5] Morrow AL, Ruiz-Palacios GM, Jiang X, Newburg DS. Humanmilk glycans that inhibit pathogen binding protect breast-feeding infants against infectious diarrhea. J Nutr 2005; 135: 1304-7.

[6] Takimori S, Shimaoka H, Furukawa JI, et al. Alteration of the $N$ glycome of bovine milk glycoproteins during early lactation. FEBS J 2011; 278: 3769-81.

[7] Takahashi N, Nakagawa H, Fujikawa K, et al. Three-dimensional elution mapping of pyridylaminated $N$-linked neutral and sialyl oligosaccharides. Anal Biochem 1995; 226: 139- 46.

[8] Yagi H, Takahashi N, Yamaguchi Y, et al. Development of structural analysis of sulfated $\mathrm{N}$-glycans by multidimensional high performance liquid chromatography mapping methods. Glycobiology 2005; 15: 1051- 60.

[9] Takahashi N, Kato K. GALAXY (glycoanalysis by the three axes of MS and chromatography):a web application that assists structural analyses of $N$-glycans. Trends Glycosci Glycotech 2003; 15: 235-51.

[10] Inagaki M, Nakaya S, Nohara $\mathrm{D}$, et al. The multiplicity of $\mathrm{N}$-glycan structures of bovine milk 18 kda lactophorin (milk GlyCAM-1). Biosci Biotechnol Biochem 2010; 74: 447-50.

[11] Kurishiro H, Motojima H. Method for the isolation of Lactophorin (in Japanese). Milk Sci 2005; 54: 85-6.

[12] Sriwilaijaroen $\mathrm{N}$, Kondo $\mathrm{S}$, Yagi $\mathrm{H}$, et al. $\mathrm{N}$-glycans from porcine trachea and lung: predominant NeuAc $\alpha 2-6 \mathrm{Gal}$ could be a selective pressure for influenza variants in favor of human-type receptor. PLoS One 2011; 6: 16302.

[13] Sriwilaijaroen N, Kondo S, Yagi $\mathrm{H}$, et al. Analysis of $N$-glycans in embryonated chicken egg chorioallantoic and amniotic cells responsible for binding and adaptation of human and avian influenza viruses. Glycoconj J 2009; 26: 433-43.

[14] Kimura M, Hara T, Kimura Y. $N$-glycans linked to glycoproteins in edible beans (zatsu-mame): natural resources for bioactive oligosaccharides. Biosci Biotechnol Biochem 2011; 75: 155-8.

[15] Menon S, Rosenberg K, Graham SA, et al. Binding-site geometry and flexibility in DC-SIGN demonstrated with surface force measurements. Proc Natl Acad Sci USA 2009; 106: 11524-9.

[16] Stanley P, Cummings RD. Structures common to different glycans. In: Varki A, Cummings RD, Esko JD, Eds. Essentials of glycobiology. Cold Spring Harbor, NY: Cold Spring Harbor Laboratory Press 2009.

[17] Hyland RM, Griener TP, Mulvey GL, et al. Basis for $\mathrm{N}$ acetyllactosamine-mediated inhibition of enteropathogenic Escherichia coli localized adherence. J Med Microbiol 2006; 55: 669-75.

[18] Varki A. Loss of $N$-glycolylneuraminic acid in humans: mechanisms, consequences, and implications for hominid evolution. Am J Phys Anthropol 2001; Suppl 33: 54-69.

[19] Hedlund M, Ng E, Varki A, Varki NM. $\alpha 2-6$-Linked sialic acids on $\mathrm{N}$-glycans modulate carcinoma differentiation in vivo. Cancer Res 2008; 68: 388-94.

[20] Delorme C, Brussow H, Sidoti J, et al. Glycosphingolipid binding specificities of rotavirus: identification of a sialic acid-binding epitope. J Virol 2001; 75: 2276-87.

[21] Schwegmann C, Zimmer G, Yoshino T, et al. Comparison of the sialic acid binding activity of transmissible gastroenteritis coronavirus and E. coli K99. Virus Res 2001; 75: 69-73.

[22] Matrosovich MN, Klenk HD, Kawaoka Y. Receptor specificity, host-range, and pathogenicity of influenza viruses. In: Kawaoka Y, Ed. Influenza virology: current topics. Wymondham: Caister Academic Press 2006; pp. 95-137.

[23] Ito T, Suzuki Y, Suzuki T, et al. Recognition of $\mathrm{N}$ glycolylneuraminic acid linked to galactose by the $\alpha 2,3$ linkage is associated with intestinal replication of influenza A virus in ducks. J Virol 2000; 74: 9300-5.

[24] Suzuki Y, Ito T, Suzuki T, et al. Sialic acid species as a determinant of the host range of influenza A viruses. J Virol 2000; 74: 11825-31. 
[25] Mukkur TK, Froese A. Isolation and characterization of IgM from bovine colostral whey. Immunochemistry 1971; 8: 257-64.

[26] Bock N, Kelm S. Binding and inhibition assays for Siglecs. Methods Mol Biol 2006; 347: 359-75.
[27] Murayama T, Zuber C, Seelentag WK, et al. Colon carcinoma glycoproteins carrying 22,6 -linked sialic acid reactive with $S a m b u$ cus nigra agglutinin are not constitutively expressed in normal human colon mucosa and are distinct from sialyl-Tn antigen. Int $\mathbf{J}$ Cancer 1997; 70: 575-81.

(C) Sriwilaijaroen et al.; Licensee Bentham Open.

This is an open access article licensed under the terms of the Creative Commons Attribution Non-Commercial License (http://creativecommons.org/licenses/by-nc/3.0/) which permits unrestricted, non-commercial use, distribution and reproduction in any medium, provided the work is properly cited. 